\title{
Effects of Prolonged Intravenous of Flunixin Meglumine in Healthy Dogs
}

\author{
H. M. ERDOGAN ${ }^{*}$, V. GUNES ${ }^{1}$, H.I. GOKCE ${ }^{1}$, M. UZUN² ${ }^{2}$ M. CITIL ${ }^{1}$, N. YUKSEK ${ }^{3}$
}

Departments of Internal Diseases ${ }^{1}$, and Physiology ${ }^{2}$, Faculty of Veterinary Medicine, University of Kafkas, Kars, Turkey; Department of Internal Medicine ${ }^{3}$ Faculty of Veterinary Medicine, University of Yuzuncu Y1l, Van, Turkey

Received April 12, 2002

Accepted November 18, 2003

\section{Abstract}

Erdogan H. M., V. Gunes, H. I. Gokce, M. Uzun, M. Citil, N. Yuksek: Effects of Prolonged Intravenous of Flunixin Meglumine in Healthy Dogs. Acta Vet. Brno 2003, 72: 71-78.

This study was designed to evaluate possible side effects on liver and kidney functions and haematological indices, associated with long-term intravenous (IV) administration of flunixin meglumine in healthy dogs. For this purpose, 12 dogs were divided into 2 equal groups. Group I was intravenously given flunixin meglumine at the dose of $1.1 \mathrm{mg} / \mathrm{kg} /$ day for 5 days and group II received $2.2 \mathrm{mg} / \mathrm{kg} /$ day IV for 5 days. Blood samples were withdrawn before treatment (day 0 ), $2 \mathrm{~h}$ post injection on each day of treatment and one day after the last injection for biochemical (glucose, sodium-Na, potassium-K, chloride- $\mathrm{Cl}$, creatinine, urea, alkaline phosphatase-AP, alanine amino transferase-ALT and total protein) and haematological (bleeding time, coagulation time, red blood cell, white blood cell, platelet count, differential leukocyte count, haematocrit and haemoglobin) analyses. Faecal and urine samples were collected on the same days as blood samples for the presence of any abnormalities. The results revealed a significant increase in bleeding $(P<0.001)$ and coagulation time $(P<0.001)$ and a decrease in platelet count $(P<0.001)$ in both groups. There was also a significant increase in the concentration of $\mathrm{Na}$ and $\mathrm{Cl}$ in group I and an elevation in $\operatorname{AP}(P<0.001), \operatorname{ALT}(P<0.001)$ and glucose $(P<0.001)$ in group II. Blood in urine and faeces was also evident in both groups. The results may suggest that the dose of 1.1 $\mathrm{mg} / \mathrm{kg}$ IV for $5 \mathrm{~d}$ does not cause any significant side effects provided that no bleeding disorder exists, and the dose of $2.2 \mathrm{mg} / \mathrm{kg}$ IV for $5 \mathrm{~d}$ should not exceed $3 \mathrm{~d}$ as liver enzymes began to increase significantly afterwards.

Flunixin meglumine, liver, kidney, haematology, dog

Non-steroidal anti-inflammatory drugs (NSAIDs) are widely used in veterinary and human medicine in the management of pain and inflammation associated with infectious or non-infectious conditions (Mc Kellar et al. 1991a; Lees et al. 1991; W at son et al. 1996; Lees et al. 2000). Their therapeutic and side effects are due to the inhibition of cyclooxygenase enzyme (COX), resulting in the blockade of eicosanoids synthesis involved in central pyresis, pain perception, tissue inflammation and pre-aggregation (Le e s et al. 1991; McKellar et al. 1991a; Lees et al. 2000). Although NSAIDs have beneficial effects as antipyretic, analgesic, antiinflammatory, antiendotoxaemic, antithrombic, anticancer and chondroprotective agents (Lees et al. 2000), their effect is offset by undesirable side effects on various organs especially the gastrointestinal tract (Rubin 1986; Dow et al. 1990; McKellar et al. 1991a).

Flunixin, an aminonicotinic acid derivative of carboxylic acid group of NSAIDs, reversibly inhibits COX and is thus a potent inhibitor of synthesis of prostaglandins and thromboxanes. It possesses, like other NSAIDs, similar beneficial and side effects (Rubin 1986; Dow et al. 1990; McKellar et al. 1991a; Lees et al. 1991; Lees et al. 2000). Flunixin has been found to reduce haemodynamic changes effectively in endotoxemic dogs (Stegelmeier et al. 1988; Bottoms et al. 1983) and to increase survival of dogs with

Address for correspondence

Dr. Hidayet Metin Erdogan

Kafkas Universitesi, Veteriner Fakultesi,

Ic Hastaliklari Bolun
Tel.: +904742426800
Fax: +904742426853

e-mail: hmerdogan

http://www.vfu.cz/acta-vet/actavet.htm 
septic peritonitis (Hardie et al. 1985a). It has also been used as an analgesic (Reid and Nolan 1991) and in the symptomatic and supportive treatment of musculoskeletal disorder and osteoarthritis (McKellar et al. 1991a; Jones and Budsberg 2000).

Flunixin has been reported to induce gastrointestinal ulcerations and nephrotoxicity (Stegelmeier et al. 1988; Dow et al. 1990; Mc Kellar et al. 1991a; Elwood et al. 1992; McNeil 1992; Vonderhaar and Salisbury 1993). It is likely that the duration of exposure to the drug to induce a toxic effect is as important as the dose administered. Therefore, the recommended dose rate is 1.0 or $1.1 \mathrm{mg} / \mathrm{kg}$ body weight ( $\mathrm{bw}$ ) for $3 \mathrm{~d}$ followed by a four-day rest period (Mc Kellar et al. 1989; Mc Kellar et al. 1991a). However, severe conditions may require higher dosages and longer duration of treatment. This necessitates satisfactory knowledge on possible side effects associated with long-term administration of flunixin.

Studies to date have mainly focused on pharmacokinetics and pharmacodynamics of flunixin meglumine (Hardie et al. 1985b; Mc Kellar et al. 1989; Mc Kellar et al. 1991b; Brideau et al. 2001). The toxic effect of the drug in dogs has been dealt with in a limited number of studies (Dow et al. 1990; Stegelmeier et al. 1988) and they usually come out of either clinical case reports (Elwood et al. 1992; McNeill 1992; Vonderhaar and Salisbury 1993) or studies in which endotoxemic dogs were used (Bottoms et al. 1983; Stegelmeier et al. 1988).

This study was therefore designed to determine the side effects, especially on liver and kidney functions and haematological parameters, associated with long term intravenous injection of two different dosages of flunixin meglumine, $1.1 \mathrm{mg} / \mathrm{kg}$ and $2.2 \mathrm{mg} / \mathrm{kg} \mathrm{bw}, \mathrm{IV}$, for $5 \mathrm{~d}$, in healthy dogs.

\section{Materials and Methods}

The study involved 12 healthy dogs of different breed, age, sex, and body weight (between 10 and $30 \mathrm{~kg}$ ). Prior to the experiment, all dogs were subjected to thorough clinical and laboratory examinations, dewormed and then observed for up to 2 weeks for any clinical signs. The dogs were housed in individual cages, and water and food were provided ad libitum both during the observational and the experimental period.

Experimental design

Animals were divided into 2 equal groups. In group I $(n=6)$, animals were intravenously (IV) given flunixin meglumine (Finadyne ${ }^{\circledR}$, Sanofi-DIF, Turkey) at the dose of $1.1 \mathrm{mg} / \mathrm{kg} / \mathrm{day}$, for $5 \mathrm{~d}$, and group II $(\mathrm{n}=6)$ received $2.2 \mathrm{mg} / \mathrm{kg} /$ day IV, for $5 \mathrm{~d}$.

Blood samples were withdrawn from the left lateral saphenous vein into the plain and EDTA-treated test tubes on each day $2 \mathrm{~h}$ post injection and one day after the last injection for haematological and biochemical analyses. Faecal and urine samples were also collected on the same days as blood samples. Faecal samples were collected from the rectum. Urine samples were taken using a sterile bladder catheter. Blood, urine and faecal samples were also collected before the administration of flunixin meglumine (day 0 ) to serve as control or baseline values.

Clinical examinations

All animals were clinically examined for any disorder on each day of the experiment. Daily rectal temperature $(\mathrm{T})$, respiratory rate $(\mathrm{RR})$ and heart rate $(\mathrm{HR}$, beats/min) were measured.

Biochemical analyses

Blood samples collected for biochemical analyses were centrifuged at $3000 \mathrm{~g}$ for 5 minutes, and serum was separated and stored at $-20{ }^{\circ} \mathrm{C}$ until analyses. Biochemical analyses included the measurement of glucose, sodium $(\mathrm{Na})$, potassium $(\mathrm{K})$, chloride $(\mathrm{Cl})$, creatinine, urea, alkaline phosphatase $(\mathrm{AP})$, alanine amino transferase (ALT) and total protein. Analyses of glucose, total protein, urea, ALP and ALT were carried out on Boehringer PHOTOMETER 5010 autoanalyser (Mannheim, Germany), using commercial kits (Diasis Diagnostic Systems, Istanbul, Turkey). Na, K, Cl and creatinine measurements were determined by Moduler-900 (Roche Diagnostics, Mannheim, Germany) using commercial kits (Roche Diagnostics, Mannheim, Germany)

Haematological analyses

Haematological analyses were performed immediately after blood sampling. Two mililitre of EDTA-treated blood was used for determination of total Red Blood Cell (RBC), White Blood Cell (WBC), Differential leukocyte, Platelet count, Haematocrit $(\mathrm{Ht})$ and Haemoglobin $(\mathrm{Hb})$. RBC, WBC and thrombocytes were counted by 
Table 1

The effect of flunixin administration on the vital parameters (mean \pm S.D.)

\begin{tabular}{|l|c|c|c|c|c|c|c|c|}
\hline \multirow{2}{*}{ Indices } & \multirow{2}{*}{ group } & \multicolumn{7}{|c|}{ Days } \\
\cline { 3 - 9 } & & 0 & 1 & 2 & 3 & 4 & 5 & 6 \\
\hline Temperature & I & $39.1 \pm 0.5$ & $38.7 \pm 0.4$ & $38.7 \pm 0.4$ & $38.9 \pm 0.4$ & $38.6 \pm 0.2$ & $38.6 \pm 0.4$ & $38.6 \pm 0.4$ \\
$\left(C^{\circ}\right)$ & II & $38.7 \pm 0.2$ & $38.6 \pm 0.4$ & $38.8 \pm 0.3$ & $38.7 \pm 0.2$ & $38.8 \pm 0.4$ & $38.8 \pm 0.4$ & $38.9 \pm 0.4$ \\
\hline Heart rate & I & $88.6 \pm 5.4$ & $88.3 \pm 6.9$ & $85.5 \pm 9.2$ & $89.1 \pm 8.3$ & $89.8 \pm 4.6$ & $91.3 \pm 2.4$ & $90.3 \pm 5.4$ \\
(Beats/min) & II & $86 \pm 11.5$ & $85.3 \pm 6.5$ & $96 \pm 14.8$ & $95.3 \pm 8.2$ & $88.7 \pm 13.5$ & $96.7 \pm 21$ & $98 \pm 11.5$ \\
\hline Respiratory & I & $29.6 \pm 4$ & $29.3 \pm 3.9$ & $31.6 \pm 5.1$ & $31.6 \pm 2.3$ & $28.6 \pm 5.3$ & $28.3 \pm 3.6$ & $28.6 \pm 3.5$ \\
Rate (min) & II & $27.3 \pm 3$ & $24.7 \pm 3$ & 24.73 & $27.3 \pm 3.9$ & $23.3 \pm 3$ & $24 \pm 3.6$ & $24 \pm 2.5$ \\
\hline
\end{tabular}

Day 0 refers to control values

haemocytometric methods using Thoma slide. Differentiation of leukocytes was made on direct observation with a microscope (Konuk 1981). Hb concentration was determined on spectrophotometer at $546 \mathrm{~nm}$. Ht was determined by microhaematocrit methods (Konuk 1981). Bleeding time was determined as follows: ears of the dogs were punctured by a blood lancet (KIP Blood lancet, Guangdong Medicines and Health Products, Guangzhou, China), and the ear was touched with filter paper (Selecta No. 589, Germany) every 30 seconds until no blood stain was seen on the paper (Konuk 1981; Willard et al. 1989). This method was deliberately chosen not to cause distress in animals. To determine coagulation time, blood was taken from right lateral saphenous vein into the plain microhaematocrit tubes, $75 \mathrm{~mm}$ long and 1.1-1.2 mm inner and 1.5-1.6 outer diameter (Superior, Germany), and the tubes were broken off every 30 seconds until the coagulation was achieved (Boddie 1969).

Table 2

Biochemical changes associated with flunixin administration (mean \pm S.D.)

\begin{tabular}{|c|c|c|c|c|c|c|c|c|}
\hline \multirow{2}{*}{ Indices } & \multirow{2}{*}{ group } & \multicolumn{7}{|c|}{ Days } \\
\hline & & 0 & 1 & 2 & 3 & 4 & 5 & 6 \\
\hline T. protein & I & $7 \pm 0.7$ & $6.9 \pm 0.8$ & $6.8 \pm 0.4$ & $6.7 \pm 0.4$ & $6.7 \pm 0.8$ & $6.4 \pm 0.7$ & $6.4 \pm 0.6$ \\
\hline (g/dl) & II & $7 \pm 0.8$ & $6.9 \pm 0.2$ & $7.2 \pm 1.0$ & $7.1 \pm 1.1$ & $7.3 \pm 0.5$ & $6.2 \pm 0.4$ & $6.9 \pm 0.8$ \\
\hline Glucose * & I & $91.3 \pm 16.7$ & $95 \pm 13.3$ & $97 \pm 9.5$ & $102.2 \pm 15$ & $97.33 \pm 9.7$ & $107.8 \pm 18.7$ & $107.2 \pm 13$ \\
\hline$(\mathrm{mg} / \mathrm{dl})$ & II & $82.7 \pm 5.6^{\mathrm{b}}$ & $79.8 \pm 3.8^{\mathrm{b}}$ & $89.7 \pm 9.9$ & $82.3 \pm 6.2^{\mathrm{b}}$ & $87.8 \pm 7.2$ & $95.3 \pm 11.6$ & $101.3 \pm 11^{\mathrm{a}}$ \\
\hline Urea & I & $10.2 \pm 3.6$ & $12.2 \pm 6.5$ & $14.1 \pm 8.0$ & $13.2 \pm 6.2$ & $13.9 \pm 6.1$ & $15.7 \pm 5.4$ & $11.98 \pm 2.6$ \\
\hline$(\mathrm{mg} / \mathrm{dl})$ & II & $6.98 \pm 1.9$ & $7.1 \pm 1.7$ & $7.25 \pm 0.8$ & $7.8 \pm 1.8$ & $6.98 \pm 1.6$ & $8.8 \pm 2.9$ & $9.9 \pm 2.6$ \\
\hline $\mathrm{AP}^{*}$ & I & $60.1 \pm 12.6$ & $66.5 \pm 18.8$ & $64.8 \pm 17.8$ & $69.3 \pm 20.1$ & $70.3 \pm 22.9$ & $78.6 \pm 18.4$ & $81.3 \pm 16.2$ \\
\hline (U/l) & II & $38.1 \pm 15.1^{b}$ & $44.1 \pm 12^{b}$ & $42 \pm 12.3^{b}$ & $44.8 \pm 13^{b}$ & $45.8 \pm 11.4^{b}$ & $57.5 \pm 6.5$ & $71 \pm 11.9^{\mathrm{a}}$ \\
\hline ALT * & I & $26.8 \pm 6.8$ & $21.8 \pm 8.7$ & $23.8 \pm 8.2$ & $25.8 \pm 7.2$ & $26.2 \pm 9.9$ & $22 \pm 11.2$ & $32.2 \pm 17.6$ \\
\hline (U/1) & II & $15.2 \pm 7.9^{b}$ & $17 \pm 6.9^{b}$ & $22.3 \pm 7.9^{b}$ & $21.7 \pm 5.9^{b}$ & $27.7 \pm 9.1$ & $28.3 \pm 9.5$ & $32.8 \pm 13.2^{\mathrm{a}}$ \\
\hline Creatinine & I & $1.1 \pm 0.3$ & $1.2 \pm 0.4$ & $1.1 \pm 0.2$ & $1.3 \pm 0.5$ & $1.25 \pm 0.4$ & $1.3 \pm 0.3$ & $1.2 \pm 0.4$ \\
\hline$(\mathrm{mg} / \mathrm{dl})$ & II & $0.9 \pm 0.1$ & $0.8 \pm 0.1$ & $0.9 \pm 0.1$ & $0.98 \pm 0.3$ & $1.1 \pm 0.5$ & $0.95 \pm 0.1$ & $1.1 \pm 0.1$ \\
\hline $\mathrm{Na} * *$ & I & $143.7 \pm 4.1^{b}$ & $147.7 \pm 4.1$ & $149.9 \pm 4.1$ & $143.3 \pm 3^{b}$ & $155.3 \pm 3.7^{a}$ & $152.8 \pm 4.9^{\mathrm{a}}$ & $145 \pm 4.2^{b}$ \\
\hline$(\mathrm{mEq} / \mathrm{l})$ & II & $136.2 \pm 5.6$ & $135 \pm 7.8$ & $140.8 \pm 8.2$ & $149.2 \pm 11$ & $146.3 \pm 9.4$ & $140.8 \pm 10.4$ & $143.3 \pm 8.9$ \\
\hline K & I & $5.1 \pm 0.5$ & $4.8 \pm 0.4$ & $5.3 \pm 0.5$ & $4.9 \pm 0.5$ & $5.4 \pm 0.5$ & $5.6 \pm 0.5$ & $5.5 \pm 0.5$ \\
\hline$(\mathrm{mEq} / \mathrm{l})$ & II & $4.3 \pm 0.7$ & $4.6 \pm 0.6$ & $5.2 \pm 0.6$ & $4.8 \pm 0.9$ & $5.3 \pm 0.9$ & $4.7 \pm 0.9$ & $5.2 \pm 0.9$ \\
\hline $\mathrm{Cl} * *$ & I & $106.7 \pm 6.5^{b}$ & $108.5 \pm 5.4$ & $108.5 \pm 7.4$ & $104.3 \pm 4.7^{b}$ & $115.2 \pm 4.8^{a}$ & $117 \pm 5.5^{\mathrm{a}}$ & $116.5 \pm 2.2^{a}$ \\
\hline$(\mathrm{mEq} / \mathrm{l})$ & II & $107.7 \pm 6.6$ & $106.8 \pm 6.7$ & $109.3 \pm 5.6$ & $109.7 \pm 6.6$ & $104.7 \pm 7.9$ & $107.3 \pm 9.7$ & $111.5 \pm 5$ \\
\hline
\end{tabular}

Values superscripted with a are significantly higher than the values superscripted with $b$ in the same row $(* P=0.001 ; * * P<0.001)$. Day 0 refers to control values 
Analyses of Urine and Faeces

Faecal samples were collected from the rectum of each dog for occult blood using Benzidin $\mathrm{HCl}$ test (Boddie 1969). Urine samples were examined using test strips (Combur 10 Test, Roche Diagnostics, Mannheim, Germany). Macroscopic and microscopic examination of urine were also made.

Statistical analysis

Values are expressed as means \pm SD and were compared using ANOVA and Tukey's test for post-injection comparisons. All analyses were done on MINITAB 12.1 (Minitab Inc., Pennsylvania, USA). Significant difference was set at $P<0.05$. No attempt was made to compare the groups since baseline values obtained for some parameters, though falling within the normal range, differed greatly.

\section{Results}

Clinical examination

All dogs survived the experimental period with no obvious clinical signs. Temperature, respiratory rate and heart rate were within the reference values in both groups (Table 1).

Biochemical findings

Blood chemistry analyses of the groups revealed a significant increase in the concentration of $\mathrm{Na}(P<0.001)$ and $\mathrm{Cl}(P<0.001)$ in group I. Na concentrations of $\mathrm{d} 4$ and 5 were significantly higher than the concentrations of $\mathrm{d} 0,3$ and 6 . The levels of chloride obtained on d 4, 5 and 6 were significantly greater than the levels of d 0 and 3 (Table 2).

Table 3

The effect of flunixin administration on haematological parameters (mean \pm S.D.)

\begin{tabular}{|c|c|c|c|c|c|c|c|c|}
\hline \multirow{2}{*}{ Indices } & \multirow{2}{*}{ group } & \multicolumn{7}{|c|}{ Days } \\
\hline & & 0 & 1 & 2 & 3 & 4 & 5 & 6 \\
\hline T. protein & I & $7 \pm 0.7$ & $6.9 \pm 0.8$ & $6.8 \pm 0.4$ & $6.7 \pm 0.4$ & $6.7 \pm 0.8$ & $6.4 \pm 0.7$ & $6.4 \pm 0.6$ \\
\hline Coagulation & I & $3.7 \pm 1.9$ & $4 \pm 2.2$ & $4.3 \pm 1.2$ & $6.5 \pm 0.9$ & $8.3 \pm 1.9$ & $15.8 \pm 1.9$ & $27.5 \pm 4$ \\
\hline time $(\min .)^{*}$ & II & $3.2 \pm 0.8$ & $8.3 \pm 2.4$ & $10.8 \pm 2.9$ & $12.2 \pm 2.6$ & $12 \pm 1.4$ & $14.7 \pm 1.6$ & $15.2 \pm 1.6$ \\
\hline Bleeding & I & $2.4 \pm 1.0$ & $3.5 \pm 0.8$ & $4.3 \pm 0.8$ & $5.6 \pm 0.8$ & $5.4 \pm 0.7$ & $6.5 \pm 0.9$ & $7.3 \pm 1.8$ \\
\hline time $(\min .)^{*}$ & II & $2.5 \pm 0.4$ & $3.8 \pm 0.4$ & $5.2 \pm 0.5$ & $5.4 \pm 0.9$ & $5.4 \pm 0.7$ & $5.8 \pm 0.5$ & $5.8 \pm 0.9$ \\
\hline Platelet & I & $2.1 \pm 0.5$ & $1.8 \pm 0.3$ & $1.4 \pm 0.2$ & $1.2 \pm 0.2$ & $0.99 \pm 0.1$ & $0.9 \pm 0.1$ & $0.7 \pm 0.2$ \\
\hline$\left(10^{5} / \mu \mathrm{l}\right)^{*}$ & II & $1.9 \pm 0.2$ & $1.8 \pm 0.3$ & $1.7 \pm 0.2$ & $1.6 \pm 0.2$ & $1.4 \pm 0.2$ & $1.2 \pm 0.2$ & $1 \pm 0.3$ \\
\hline $\mathrm{RBC}$ & I & $4.4 \pm 0.8$ & $4.5 \pm 0.9$ & $4.9 \pm 0.8$ & $4.7 \pm 0.8$ & $5 \pm 0.8$ & $4.9 \pm 0.4$ & $4.8 \pm 0.9$ \\
\hline$\left(10^{6} / \mu \mathrm{l}\right)$ & II & $6.4 \pm 1.2$ & $6.5 \pm 1$ & $6.4 \pm 1.2$ & $6 \pm 0.8$ & $6.2 \pm 0.5$ & $5.6 \pm 0.7$ & $5.6 \pm 0.6$ \\
\hline WBC & I & $5.8 \pm 3.7$ & $5.7 \pm 3.1$ & $5.6 \pm 3$ & $5.7 \pm 3.2$ & $6 \pm 3.1$ & $6.2 \pm 3.2$ & $6.6 \pm 3.4$ \\
\hline$\left(10^{3} / \mu \mathrm{l}\right)$ & II & $15.9 \pm 1.5$ & $15.9 \pm 2.2$ & $17.2 \pm 3.1$ & $16.3 \pm 5.8$ & $16.4 \pm 2$ & $17.1 \pm 3.5$ & $17.4 \pm 3.4$ \\
\hline Hematocrit & I & $39.1 \pm 6.5$ & $41 \pm 7.4$ & $41.8 \pm 6$ & $41 \pm 4.3$ & $404 \pm 6$ & $39.3 \pm 4$ & $39.1 \pm 3.1$ \\
\hline$(\%)$ & II & $43 \pm 4$ & $42.8 \pm 4$ & $42.3 \pm 5.1$ & $41 \pm 3$ & $42.1 \pm 4.5$ & $43 \pm 5.4$ & $42.6 \pm 5.3$ \\
\hline Hemoglobin & I & $11 \pm 1.9$ & $13.2 \pm 3.4$ & $12.1 \pm 2.4$ & $10.3 \pm 1.7$ & $10.8 \pm 1.2$ & $10.6 \pm 1.1$ & $10.9 \pm 1.2$ \\
\hline (g/dl) & II & $11.9 \pm 1.2$ & $12 \pm 1$ & $14.1 \pm 2$ & $11.9 \pm 1.1$ & $12.6 \pm 1.5$ & $12.9 \pm 1.5$ & $12.7 \pm 1.9$ \\
\hline Neutrophils & I & $60.8 \pm 9.2$ & $66.3 \pm 15.2$ & $74.5 \pm 10.1$ & $72 \pm 10.7$ & $74.6 \pm 4.6$ & $69.3 \pm 10.3$ & $71.5 \pm 5.5$ \\
\hline$(\%)$ & II & $76.3 \pm 6.2$ & $78.5 \pm 4.1$ & $67.6 \pm 7.9$ & $71 \pm 9.4$ & $65.3 \pm 11.1$ & $68 \pm 10.4$ & $72.5 \pm 10.7$ \\
\hline Lymphocytes & I & $39.6 \pm 11$ & $31.8 \pm 10.7$ & $23.8 \pm 10.2$ & $26.5 \pm 11$ & $23.8 \pm 5.4$ & $31.5 \pm 10.2$ & $27.1 \pm 5.7$ \\
\hline$(\%)$ & II & $21.6 \pm 5.9$ & $15.2 \pm 3.5$ & $27.2 \pm 7$ & $20.2 \pm 7.3$ & $21.2 \pm 6.6$ & $18.2 \pm 6.7$ & $19 \pm 8.9$ \\
\hline Monocytes & I & $3.3 \pm 1$ & $3 \pm 0.8$ & $2.8 \pm 0.7$ & $2.3 \pm 1.3$ & $2.6 \pm 0.8$ & $2.3 \pm 1.2$ & $2.5 \pm 0.8$ \\
\hline$(\%)$ & II & $3 \pm 0.6$ & $3.3 \pm 1.7$ & $2.8 \pm 1.1$ & $4 \pm 1.4$ & $3.8 \pm 1.1$ & $4.1 \pm 0.9$ & $3.6 \pm 0.5$ \\
\hline Eosinphil & I & $3.3 \pm 0.5$ & $3 \pm 0.6$ & $3.1 \pm 1.3$ & $3 \pm 0.6$ & $3.3 \pm 0.5$ & $3.2 \pm 1.1$ & $3.3 \pm 0.5$ \\
\hline$(\%)$ & II & $3.5 \pm 0.8$ & $3.8 \pm 0.7$ & $3.8 \pm 0.4$ & $4 \pm 0.8$ & $5 \pm 0.9$ & $4.8 \pm 1.3$ & $4.5 \pm 1.4$ \\
\hline
\end{tabular}

* coagulation and bleeding time increased $(P<0.001)$ and platelet count decreased $(P<0.001)$ in both groups, Day 0 refers to control values, RBC: Red Blood Cell, WBC: White Blood Cell 
Table 4

Urine changes associated with flunixin meglumine administration (mean \pm S.D.)

\begin{tabular}{|l|c|c|c|c|c|c|c|c|}
\hline \multirow{2}{*}{ Indices } & \multirow{2}{*}{ group } & \multicolumn{7}{|c|}{ Days } \\
\cline { 3 - 9 } & & 0 & 1 & 2 & 3 & 4 & 5 & 6 \\
\hline Urine & I & $1.018 \pm 5.2$ & $1.017 \pm 6$ & $1.020 \pm 6.3$ & $1.019 \pm 5.8$ & $1.023 \pm 5.1$ & $1.018 \pm 8.1$ & $1.021 \pm 3.7$ \\
density & II & $1.017 \pm 4$ & $1.018 \pm 5.2$ & $1.019 \pm 5.8$ & $1.024 \pm 2$ & $1.021 \pm 3.7$ & $1.018 \pm 7.5$ & $1.017 \pm 6$ \\
Urine & I & $5.6 \pm 0.5$ & $5.3 \pm 0.5$ & $6 \pm 0.8$ & $6.1 \pm 0.4$ & $6.1 \pm 0.7$ & $5.8 \pm 0.9$ & $5.6 \pm 0.8$ \\
pH & II & $5.8 \pm 0.7$ & $6 \pm 0.6$ & $6 \pm 0.5$ & $5.8 \pm 0.7$ & $6.3 \pm 0.5$ & $6 \pm 1.2$ & $6.6 \pm 0.8$ \\
Urine & I & - & - & ++ & + & ++ & ++ & ++ \\
blood & II & - & - & - & ++ & ++ & ++ & ++ \\
Urine & I & - & - & - & + & ++ & ++ & ++ \\
protein & II & - & - & - & + & + & ++ & ++ \\
Urine & I & - & - & - & + & +++ & +++ & +++ \\
leukocyte & II & - & - & - & +++ & +++ & +++ & +++ \\
\hline
\end{tabular}

- negative, + weak positive, ++ mild positive, +++ strong positive, Day 0 refers to control values

A significant increase in AP $(P=0.001)$, ALT $(P=0.001)$ and glucose $(P=0.001)$ concentrations in group II was also noted. AP value determined on d 6 was greater than the values obtained on $\mathrm{d} 0,1,2,3$ and 4 . ALT concentration obtained on $\mathrm{d} 6$ was higher than the concentrations of $\mathrm{d} 0,1,2$ and 3 . As for glucose, values obtained on d 6 significantly differed from the values of $\mathrm{d} 0,1$ and 3 (Table 2). No significant changes were noticed in other parameters examined in both groups (Table 2).

Haematological findings

There was a statistically significant decrease in platelet count $(P<0.001)$ and a significant increase in the duration of bleeding $(P<0.001)$ and coagulation $(P<0.001)$ time when compared with baseline values in both groups. The changes in other haematological parameters were non-significant (Table 3)

Table 5

Occult blood findings in the faeces of dogs in group I and II

\begin{tabular}{|c|c|c|c|c|c|c|c|c|c|c|c|c|c|c|}
\hline \multicolumn{8}{|c|}{ Group I } & \multicolumn{7}{|c|}{ Group II } \\
\hline \multicolumn{8}{|c|}{ Days } & \multicolumn{7}{|c|}{ Days } \\
\hline Dogs & 0 & 1 & 2 & 3 & 4 & 5 & 6 & 0 & 1 & 2 & 3 & 4 & 5 & 6 \\
\hline 1 & - & - & + & + & + & + & + & - & - & - & - & + & + & + \\
\hline 2 & - & - & - & + & + & + & + & - & - & - & + & + & + & + \\
\hline 3 & - & - & - & + & + & + & + & - & - & - & - & + & + & + \\
\hline 4 & - & - & + & + & + & + & + & - & - & - & + & + & + & + \\
\hline 5 & - & - & + & + & + & + & + & - & - & - & + & + & + & + \\
\hline 6 & - & - & + & + & + & + & + & - & - & - & - & + & + & + \\
\hline
\end{tabular}

- negative, + positive, Day 0 refers to control values

Urine and faecal findings

The analyses of urine samples revealed no significant changes in urine $\mathrm{pH}$ and density in both groups however test strips were positive for blood on day 2 and 3 in group I and II respectively. Positive results for urine protein and leukocytes were obtained on $\mathrm{d} 3$ in both groups and they remained positive throughout the experimental period. Microscopic examination of urine sediment revealed no abnormalities apart from few 
leukocytes and erythrocytes (Table 4). Macroscopic examination of the urine revealed no changes.

Occult blood test for group I was positive for 3 dogs on $\mathrm{d} 2$ and for all dogs on $\mathrm{d} 3$ and it remained positive throughout the study. In group II, positive results were obtained on d 3 for 3 dogs and for all dogs on $\mathrm{d} 4$ and thereafter (Table 5).

\section{Discussion}

This study evaluated the effect of prolonged intravenous injection of flunixin in healthy dogs on liver, kidney and haematological parameters. Statistical comparison between the groups was not made. However, the comparison within the groups revealed significant increase in bleeding time, coagulation time and a decrease in platelet count in both groups. These findings are in agreement with the side effects reported for flunixin and NSAIDs at large (McKellar et al. 1991a; Lees et al. 2000). Flunixin inhibits thromboxane $\mathrm{A}_{2}$, a potent stimulator of platelet aggregation and vascular smooth muscle contraction, essential components of coagulation, resulting in increased bleeding and coagulation time (McKellar et al. 1989; McKellar et al. 1991b; Lees et al. 2000). Another reason for this is thrombocytopenia (Willard et al. 1989) that was also the case in this study. There was a significant decrease in the number of platelets. There is a controversy in the literature as regard to the platelet count. McKellar et al. (1989 and 1991b) found the platelet count within normal range while Hardie et al. (1985a) found a decrease in the platelet count in septic dogs whose treatments involved flunixin meglumine. Decreased platelet count may be attributed to the external bleeding that was also evident in urine and faeces in this study. However, the changes in other haematological parameters examined were not significant.

The presence of blood in faeces in this study is also in accordance with other reports (McKellar et al. 1989; Dow et al. 1990). This is a normal finding for dogs not receiving any medication (McKellar et al 1989; McKellar et al 1991b). However, the presence of the occult blood was a consistent finding after the $3 \mathrm{rd}$ and the 4 th day of experiment in group I and II respectively. This may suggest that occult blood in faeces may have arisen from a bleeding due possible to gastrointestinal ulceration associated with flunixin administration which is well documented (Dow et al. 1990; Vonderhaar and Salisbury 1993).

Increase in ALT level in the dogs of group II may suggest a hepatic damage as ALT is mainly released by hepatocytes in dogs (Willard et al. 1989). As the duration of flunixin administration increased the concentration of the ALT also increased. However, even the highest concentration obtained in this study fell within the normal range reported for dogs (Kaneko et al. 1997). Drug administration in general such as salicylates and flunixin is reported to cause elevation in ALT level (Willard et al. 1989; Taylor et al. 1994). This may also reflect a mild hepatopathy, if any. AP increase was also within the reference ranges (Kaneko et al. 1997). AP elevation should be three times more than the normal value in order to be indicative of any pathological changes in the liver (Willard et al. 1989). However, the increase was two fold of the baseline values and it was only significantly high on the last day of experiment in this study.

Elevation in glucose concentration has been associated with NSAIDs administration (Willard et al. 1989). The mechanism by which glucose increase is induced, remains unclear. The levels obtained for glucose in this study were also within the reference ranges (Willard et al. 1989; Kaneko et al. 1997).

$\mathrm{Na}$ and $\mathrm{Cl}$ increase in group I may indicate an electrolyte imbalance. Prostaglandin inhibition in the kidney results in decreased blood flow and increased Na retention (Rubin 1986; Jones and Budsberg 2000). This may explain the elevation of $\mathrm{Na}$ and $\mathrm{Cl}$ concentrations. It may also be a chance finding as the elevation in $\mathrm{Na}$ and $\mathrm{Cl}$ was not seen 
in group II. These values were also within the ranges normally expected for dogs (Willard et al. 1989; Kaneko et al. 1997).

Urine density and $\mathrm{pH}$ were semi-quantitatively determined using test strips which may not reflect the accurate values but other parameters, evaluated for possible nephrotoxicity were normal. Non-significant changes in creatinin and urea levels indicate the absence of nephrotoxicity associated with flunixin administration (Reid and Nolan 1991; Elwo od et al. 1992). Reports indicate that NSAIDs do not induce an adverse effect on the renal functions in healthy individuals (Rubin 1986; Jones and Budsberg 2000). Presence of leukocytes and erythrocytes may be due to a pathological event in bladder due possible to the catheterisation.

The parameters examined, except for bleeding and coagulation time and platelet count, were all within the reference range normally expected for dogs (Willard et al.1989; Kanek o et al. 1997). This study may therefore suggest that flunixin administered at a dose of $1.1 \mathrm{mg} / \mathrm{kg}$ IV for $5 \mathrm{~d}$ does not cause significant changes in the liver and the kidney provided that no bleeding disorder exists. However, caution should be exercised when the dose of $2.2 \mathrm{mg} / \mathrm{kg}$ is given IV. For the first three days of the experiment, the increase in ALT, $\mathrm{AP}$ and glucose concentrations were not significant but the values obtained on the last day of the experiment were significantly higher than the baseline and $\mathrm{d} 3$ values. This may suggest that intravenous injection of $2.2 \mathrm{mg} / \mathrm{kg}$ should not exceed 3 days.

\section{Vliv prolongované intravenózní aplikace flunixin megluminu na zdravé psy}

Cílem předkládané práce bylo zhodnotit případné vedlejší účinky na funkci jater, ledvin a hematologické ukazatele zdravých psů po dlouhodobé intravenózní (i.v.) aplikaci flunixin megluminu. Za tímto účelem bylo 12 psů rozděleno do dvou stejně velkých skupin. Ve skupině I byl flunixin meglumin podáván intravenózně v dávce $1.1 \mathrm{mg} / \mathrm{kg} / \mathrm{den}$ po dobu 5 dnů. Psům ve skupině II byla aplikována dávka $2.2 \mathrm{mg} / \mathrm{kg} / \mathrm{den}$ rovněž intravenózně po dobu 5 dnů. Psům byly pravidelně odebírány vzorky krve - před zahájením první aplikace (den 0), každý den $2 \mathrm{~h}$ po provedené aplikaci a den po poslední aplikaci. Vzorky krve sloužily jednak pro biochemické vyšetření [glukóza, sodík, draslík, chlór, kreatinin, urea, alkalická fosfatáza (AP), alanin - amino transferáza (ALT) a celkové bílkoviny] a jednak pro hematologickou analýzu (krvácení, rychlost srážlivosti krve, počet červených krvinek, počet bílých krvinek, počet krevních destiček, diferenciální počet leukocytů, hematokrit a hemoglobin). Vzorky trusu a moče byly odebírány v týchž dnech jako vzorky krve a sloužily pro sledování jakýchkoliv odchylek. Na základě získaných výsledků byl zjištěn signifikantní vzestup krvácivosti $(P<0.001)$ a srážlivosti krve $(P<0.001)$ a pokles počtu krevních destiček $(P<0.001)$ v obou sledovaných skupinách. Rovněž byl zjištěn signifikantní vzestup koncentrace sodíku a chlóru ve skupině I a v elevaci AP $(P<0.001)$, ALT $(P<0.001)$ a glukózy $(P<0.001)$ ve skupině II. V obou sledovaných skupinách byla zjištována krev v trusu a moči psů. Z uvedených výsledků lze předpokládat, že dávka $1.1 \mathrm{mg} / \mathrm{kg}$ aplikovaná i.v. po dobu 5 dnů nezpůsobuje žádné vedlejší př́iznaky, nebyly zjištěny žádné krvácivé stavy. Dávka $2.2 \mathrm{mg} / \mathrm{kg}$ i.v. podávaná po dobu 5 dnů měla za následek signifikantní vzestup jaterních enzymů, a proto by podávání této dávky nemělo přesáhnout období 3 dnů.

\section{References}

BRIDEAU, C., VAN STADEN, C., CHAN, C.C. 2001: In vitro effects of cyclooxygenase inhibitors in whole blood of horses, dogs, and cats. Am J Vet Res 62:1755-1760

BODDIE, G.F. 1969: Diagnostic Methods in Veterinary Medicine. $7^{\text {th }}$ ed. Oliver and Boy. Edinburgh. UK., pp. 323-324; 384-385.

BOTTOMS, G.D., JOHNSON, M.A., ROESEL, O.F. 1983: Endotoxin-induced hemodynamic changes in dogs: Role of thromboxane and prostaglandin $\mathrm{I}_{2}$. Am J Vet Res 44:1497-1500

DOW, S.W., ROSYCHUK, R.A.W., MCCHESNEY, A.E., CURTIS C.R. 1990: Effects of flunixin and flunixin plus prednisone on the gastointestinal tract of dogs. Am J Vet Res 52:1131-1138 
ELWOOD, C., BOSWOOD, A., SIMPSON, K., CARMICHAEL, S. 1992: Renal failure after flunixin meglumine administration. Vet Rec 130:582-583

HARDIE, E.M., RAWLINGS, C.A., COLLINS, G.L. 1985a: Canine Escherichia coli peritonitis: Long-term survival with fluid, gentamicin sulfate, and flunixin meglumine treatment. J Am Anim Hosp Assoc 21:691-699

HARDIE, E.M., HARDIE, G.E., RAWLINGS, C.A. 1985b: Pharmacokinetics of flunixin meglumine in dogs. Am J Vet Res 46:235-237

JONES, C.J., BUDSBERG, S.C. 2000: Physiological characteristics and clinical importance of the cyclooxygenase isoforms in dogs and cats. J Am Vet Med Assoc 217:721-729

KANEKO, J.J., HARVEY, J.W., BRUSS, M.L. 1997: Clinical Biochemistry of Domestic Animals. $5^{\text {th }}$ ed. Academic Press, London. UK., pp. 895-899.

KONUK, T. 1981: Pratik Fizyoloji I., 2. Bask1, A.Ü. Basımevi, Ankara, pp. 55-118.

LEES, P., LENDONI, M.F., ARMSTRONG, S., FREAN, S. 2000: New insight into inflammation with particular reference to the role of COX enzymes. $8^{\text {th }}$ International Congress of the European Association for Veterinary Pharmacology and Toxicology. Jerusalem, Israel.

LEES, P., MAY, S.A., McKELLAR, Q.A. 1991: Pharmacology and therapeutics of non-steroidal antiinflammatory drugs in dog and cat: 1 General pharmacology. J Small Anim Pract 32:183-193

McKELLAR, Q.A., MAY, S.A., LEES, P. 1991a: Pharmacology and therapeutics of non-steroidal antiinflammatory drugs in dog and cat: 2 Individual agents. J Small Anim Pract 32:225-235

McKELLAR, Q.A., GALBRAITH, E.A., BOGAN, J.A., RUSSELL, C.S., HOOKE, R.E., LEES, P. 1989: Flunixin meglumine pharmacokinetics and serum thromboxane inhibition in dogs. Vet Rec 124:651-654

McKELLAR, Q.A., GALBRAITH, E.A., SIMMONS, R.D. 1991b: Pharmacokinetics and thromboxane inhibition of two NSAIDs when administered to dogs by intravenous or subcutaneous route. J Small Anim Pract 32:335340

McNEIL, P.E. 1992: Acute tubulo-interstitial nephritis in a dog after halothane anaesthesia and aministration of flunixin meglumine and trimethoprim-sulphadiazine. Vet Rec 131:148-151

REID, J., NOLAN, A.M. 1991: A comparison of the postoperative analgesic and selective effects of flunixin and papaveratum in the dog. J Small Anim Pract 32:603-608

RUBIN, S.I. 1986: Nonsteroidal antiinflammatory drugs, prostaglandins, and the kidney. J Am Vet Med Assoc 188:1065-1068

STEGELMEIER, B.L., BOTTOMS, G.D., DENICOLA, D.B., REED, W.M. 1988: Effects of flunixin meglumine in dogs following experimentally induced endotoxemia. Cornell Vet 78:221-230

TAYLOR, P.M., WINNARD, J.G., JEFFERIES, R., LEES, P. 1994: Flunixin in the cat: A pharmacodynamic, pharmacokinetic and toxicological study. Br. Vet. J. 150: 253-261.

VONDERHAAR, M.A., SALISBURY, S.K. 1993: Gastroduodenal ulceration associated with flunixin meglumine administration in three dogs. J Am Vet Med Assoc 203:92-95

WATSON, A.D.J., NICHOLSON, A., CHURCH, D.B., PEARSON, M.R.B. 1996: Use of anti-inflammatory and analgesic drugs in dogs and cats. Aust Vet J 74:203-210

WILLARD, M.D., TVEDTEN, H., TURNWALD, G.H. 1989: Small Animal Clinical Diagnosis by Laboratory Methods. W.B. Saunders Company, Philadelphia, USA., pp. 90-91; 108-114; 162; 217-219; 362-363. 